\title{
DIGITAL COMMUNITY DEVELOPMENT: MEDIA PELESTARIAN KEARIFAN LOKAL WISATA JURANG TOLEH KABUPATEN MALANG
}

\author{
Sri Widayati ${ }^{1}$ | Muhammad Hanif Fahmi ${ }^{2}$ | Lian Agustina Setiyaningsih ${ }^{1} \mid$ \\ Aryo Prakoso Wibowo ${ }^{1}$
}

${ }^{1}$ Program Studi IImu Komunikasi, FISIP, Universitas Merdeka

Malang, Jalan Terusan Raya

Dieng 62-64 Malang, Jawa Timur 65115

2Program Studi Sistem Informasi, Fakultas Sains dan Teknologi, Universitas Islam Raden Rahmat Jalan Mojosari Kepanjen, Kabupaten Malang, Jawa Timur 65163

Correspondence

Muhammad Hanif Fahmi

Program Studi Sistem Informasi, Fakultas Sains dan Teknologi, Universitas Islam Raden Rahmat Email: hanif@uniramalang.ac.id

http://doi.org/10.26905/nomosleca.v $7 i 1.5490$

\begin{abstract}
The global challenge preserving local wisdom is in social adjustment to technology adoption. Communities can accelerate use of technology to preserve local wisdom. Jatiguwi, through Jurang Toleh Park, has become a pilot project in digitally empowering communities to carry out local wisdom and improve the economy of rural communities. A qualitative descriptive method involving four informants based on the following criteria: involvement village activities, actively participating village activities, and being involved village tourism activities. The sampling technique used was purposive sampling, data analysis technique used Miles and Huberman's analysis. This research emphasizes on digital empowerment efforts for the community to preserve local wisdom and strengthen the village economy. The result of this research is that the success of digital empowerment starts with digital understanding by the community. Then involvement in developing tourism potential, visitor management of tourism and tourism promotion. These four things are realized through independent training by the community.
\end{abstract}

Keywords: Digital Community Development, Local Wisdom, Empowerment Media

\begin{abstract}
Abstrak: Tantangan global dalam melestarikan kearifan lokal adalah penyesuaian masyarakat pada adopsi teknologi. Kelompok melakukan akselerasi teknologi untuk melestarikan kearifan lokal daerahnya. Desa Jatiguwi melalui Jurang Toleh Park, menjadi pilot project dalam pemberdayaan komunitas digital guna melestarikan kearifan lokal serta meningkatkan perekonomian masyarakat desa. Metode deskriptif kualitatif dengan melibatkan empat informan berdasarkan kriteria: keterlibatan dalam kegiatan desa, berpartisipasi aktif, dan berkecimpung dalam kegiatan wisata desa. Teknik sampling adalah purposive sampling, sedangkan teknik analisa data Miles dan Huberman. Penelitian ini menekankan pada upaya pemberdayaan digital kepada komunitas untuk melestarikan kearifan lokal dan memperkuat perekonomian desa. Hasil penelitian keberhasilan pemberdayaan digital dimulai dari pemahaman digital oleh masyarakat. Kemudian keterlibatan dalam mengembangkan potensi wisata, pengunjung pengelolaan wisata dan promosi wisata.
\end{abstract}

Kata Kunci: Digital Community Development, Kearifan Lokal, Media Pemberdayaan. 


\section{1 | PENDAHULUAN}

Desa Jatiguwi terletak di Kabupaten Malang, memiliki potensi wisata berbasis kearifan lokal. Penduduk setempat masih sangat memperhatikan budaya lokal mayarakat pedesaan dan menjunjung nilai lokal yang ada di masyarakat. Bagi masyarakat setempat kearifan lokal yang dianggap aset untuk dijaga berupa sumber daya alam dan nilai gotong royong untuk membangun desa. Nilai kearifan lokal pada desa idealnya dilestarikan oleh kelompok masyarakat, karena kelompok mampu melakukan integrasi nilai (Mungmachon, 2012), mengekspos dan eksplorasi (Qamar et al., 2017) serta mendidik masyarakatnya sendiri (Uge \& Yasin, 2019; Widodo et al., 2019). Hal ini dikarenkan konsep kearifan lokal dapat digambarkan sebagai aset lokal dari suatu masyarakat di sebuah daerah yang juga mampu mendatangkan kesejahteraan secara ekonomi. Dalam Keraf (2002) kearifan lokal dideskripsikan sebagai semua bentuk pengetahuan, keyakinan, pemahaman, atau wawasan serta adat kebiasaan atau etika yang menuntun perilaku manusia dalam kehidupan di dalam kelompok ekologis. Sedangkan menurut Gobyah (2009) kearifan lokal merupakan kebenaran yang mentradisi dalam suatu daerah. Dengan kata lain masyarakat Jatiguwi adalah representasi kehidupan masyarakat pedesaan yang masih belum banyak terkontaminasi modernisasi.

Di tengah globalisasi, pelestraian kearifan lokal yang bertujuan untuk meningkatkan perekonomian desa dapat dilakukan melalui komunikasi pemberdayaan kelompok. Potensi desa yang dimiliki menjadi kekuatan dalam meningkatkan perekonomian desa berbasis kelompok. Salah yang menjadi kearifan lokal adalah hamparan waduk yang dipenuhi dengan ratusan karamba budidaya ikan air tawar yang merupakan penghasilan utama masyarakat Dukuh Jatiguwi selain hasil pertanian. Selain itu, pemandangan sore hari saat matahari tenggelam (sun set) di area waduk begitu indah sehingga menarim perhatian. Community development merupakan sebuah konsep sentral dan prinsip dasar dari pemberdayaan kelompok masyarakat. Peningkatan partisipasi masyarakat merupakan salah satu output dari community development yang berorientasi pada pencapaian hasil pelaksanaan yang dilakukan masyarakat (Ife, 2009).

Pengelolahan kearifan lokal berbasis kelompok merupakan upaya untuk meningkatkan kapasitas masyarakat itu sendiri. Tujuan utamanya adalah terjadinya transformasi masyarakat ke arah masyarakat modern perlu dimulai dengan pemahaman bahwa masyarakat sebagai sistem sosial yang didalamnya struktural, budaya, dan sosial (Selasih \& Sudarsana, 2018). Proses yang dimaksudkan di atas meliputi faktor yang menyebabkan perubahan masyarakat dengan pandangan 
dasar yakni masyarakat perlu mendapatkan pendidikan untuk mengelola sumber daya kelompok dan untuk menghadapi tantangan globalisasi (Albantani \& Madkur, 2018). Kekuatan kelompok dibutuhkan untuk menghadapi tantangan, persaingan dan ketidakpastian atas globalisasi. Hal ini dimaksudkan untuk membangun paradigm, strategi dan model pembelajaran bagi masyarakat agar mampu beradaptasi dengan akselerasi perubahan teknologi di desa.

Pengembangan masyarakat bertujuan untuk memberdayakan masyarakat yang dilakukan melalui usaha-usaha terorganisir untuk memperbaiki kondisi kehidupan masyarakat, serta meningkatkan kemampuan masyarakat. Proses yang ditempuh melalui kegiatan yang terintegritas dan bertumpu pada kemandirian sehingga lebih bernuansa pembangunan berkelanjutan. Pemebderdayaan berbasis kelompok seperti misalnya pada ibu rmah tangga, kelompok pemuda dan pemerintah desa menjadi inti dari perubahan yang terjadi di desa (Setiyaningsih, 2017; Boedijono et al., 2019; Syairozi et al., 2019; Setiyaningsih \& Fahmi, 2020). Community development, corporate social responsibility (CSR) perusahaan dilakukan bersama kelompok (masyarakat) sekitar dengan kegiatan sejenis pengembangan masyarakat lokal atau community development. Kelompok dan CSR memiliki irisan untuk diperjuangkan. Namun pelaksanaannya harus juga berbasis pada kearifan lokal agar tercipta community development yang sehat (Handiwibowo, 2018; Umanailo, 2019; Yuliasari, 2020)

Community development (pengembangan masyarakat) adalah upaya mengembangkan sebuah kondisi masyarakat secara berkelanjutan dan aktif berdasarkan prinsip-prinsip keadilan sosial dan saling menghargai. Pengembangan masyarakat berhubungan dengan upaya pemenuhan kebutuhan, baik yang disebabkan oleh kemiskinan maupun diskriminasi berdasarkan kelas sosial, suku, gender, jenis kelamin, usia dan kecacatan. Berbagai permasalahan di masyarakat dapat diselesaikan dengan bertumpu pada kekuatan kelompok yang ada dimasyarakat seperti pada kasus covid 19 melalui sosialisai hidup sehat (Sufiyanto et al., 2020), mitigasi banjir berbasis kelompok siaga (Wardhono et al., 2020), peningkatan wisata gunung kidul berbasis komunikasi kelompok inovatif (Sekarningrum et al., 2020). Berdasarkan kegiatan di atas, kesuksesan peningkatan kapasistas masyarakat dapat terlaksana dengan berbasis kekuatan kelompok. Kelompok mampu mengetahui potensi dasar dari daerah masing-masing.

Selain unsur kapasitas kelompok atau kelompok yang menentukan keberhasilan dalam pengelolaan kearifan lokal, terdapat unsur media kelompok. Media kelompok merupakan wadah yang mampu menjebatani dan memfasilitasi kebutuhan serta menciptakan solusi atas permasalahan lokal dalam masyarakat. Melalui media kelompok, kelompok maupun kelompok dapat melakukan jejaring yang lebih optimal. Dalam Suri (2019), media kelompok dapat berdampak positif 
bagi kelompok dan kelompok untuk mengembangkan kapasitas diri dan lingkungan, terutama dalam mengelola kearifan lokal di desa. Selain itu dalam Farady Marta et al., (2019) menyebutkan bahwa kepatuan kelompok alam pemanfaatan media menjadi factor pendukung efektifnya penggunaan media.

Dalam rangka menghadapi era digital, proses komunikasi pembangunan dapat diadaptasikan juga dengan komunikasi digital. Proses penyelenggaraan pemberdayaan terhadap masyarakat juga dikolaborasikan dengan menggunakan metode yang mengadopsi budaya digital. Media komunikasi yang dimiliki oleh masyarakat juga melalui adaptasi budaya digital. Sebab kebiasaan digital pada awalnya menimbulkan gegar budaya dan kebiasaaan. Namun, seiring dengan berjalannya waktu dan proses yang dialami oleh masyarakat maka kebiasaan tersebut dapat diadopsi dengan baik. Media komunikasi yang berbasis digital dapat dimanfaatkan secara optimal untuk melestarikan kearifan lokal desa. Masyarakat dapat perpartisipasi aktif dan langsung dalam pemanfaatan media tereseut, terutama dalam melibatkan kelompok dan kelompok (Setyowati, 2019).

Komunikasi pembangunan yang berupa pemberdayaan masyarakat meliputi strategi strategi yang berpusat pada kebutuhan guna melakukan sosialisasi kegiatan kepada kelompok maupun kelompok. Lingkup kegiatan yang ditujukan meliputi untuk mengubah sikap, pendapat, dan perilakunya guna meningkatkan kemajuan eksternal dan kepuasan internal. Pemberdayaan yang berupa community development menepatkan masyarakat setara dan bias secara mandiri mengembangkan potensi (Akbar et al., 2019). Dengan kata lain, kelompok dan kelompok memiliki peran dominan dalam melestarikan kearifan lokal. Hal ini disebabkan solusi dan pengambilan keputusan pada dasarnya terletak pada masyarakat desa sendiri. Namun, yang terjadi selama ini adalah masyarakat tidak menyadari akan potensi tersebut sehingga permasalahan menumpuk dan dibiarkan begiru saja. Pada akhirnya masyarakat tidak bias mengenali secara mandiri potensi yang ada di desa. Yang berakibat pada menumpuknya permasalahan dalam pengelolaan kearifan lokal. Padahal, kearifan lokal merupakan potensi desa yang sangat dekat dengan masyarakat desa itu sendiri.

Kondisi lingkungan di JTP menyiratkan kearifan lokal secara alamiah. Oleh karenanya eksplorasi kearifan lokal yang dilakukan oleh masyarakat sekitar membawa dampak positif bagi perkembangan kondisi masysarakat. Namun, selama ini beberapa hal yang telah dilakukan di daerah tersebut guna meningkatkan potensi wilayah masih belum maksimal. Dalam Widayati et al., (2019) pendampingan di desa Jatiguwi telah menggunakan asas pemanfaatan potensi desa. Kegiatan tersebut dilakukan melalui pendampingan pembenahan fisik area wisata. Cakupan ruang kegiatan menyasar pada perombakan dan pembangunan fisik bangunan dan pengorganisiran sampah serta penyediaan sarana dan 
prasarana. Peningkatan kapasistas masyarakat lokal dengan pemberian pelatihan keterampilan menjamu wisatawan dan mengelola ekowisata menjadi program pemberdayaan. Seluruh upaya yang dilakukan untuk mengembangkan potensi desa, melestarikan keraifan lokal, meingkatkan kualitas sumber daya manusia serta meningkatkan pendapata dan kesejahteraan masyarakat desa.

Upaya yang telah dilakukan menunjukkan progres yang belum maksimal, terutama pada aspek promosi wisata. Untuk menjawab tantangan global, dimana semua aspek kehidupan berbasis media digital, maka diperlukan strategi pemberdayaan yang tepat. Terutama melihat dari berbagai kajian di atas bahwa pelibatan kelompok maupun kelompok merupakan kekuatan untuk mengembangkan potensi desa dan pendapatan masyarakat setempat. Oleh karenanya penelitian ini mengkaji dari aspek strategi pengembangan kelompok perekonomian masyarakat berbasis digital. Mengingat perkembangan teknologi yang cukup massif, adaptasi teknologi dan budaya digital juga harus dikenalkan kepada masyarakat. Hal ini berfungsi untuk meningkatkan kemampuan masyarakat dalam keterampilan pemanfaatan teknologi. Sehingga batasan penelitian ini terletak pada pengembangan kapasitas kelompok untuk mengelola kearifan lokal berbasis digital.

\section{2 | METODE PENELITIAN}

Penelitian ini menggunakan metode deskriptif kualitatif. Data yang didapat berupa informasi yang bersifat kelitatif (Sugiyono, 2017). Data kualitatif berupa informasi dan fakta mengenai upaya digital community development dalam rangka melestarikan kearifan lokal desa. Teknik sampling yang digunakan adalah purposive sampling, dikarenakan memilih informan berdasarkan kriteria sesuai dengan kebutuhan penelitian. Adapun kriteria dari informan meliputi a) memiliki keterlibatan dalam kegiatan desa, b) berpartisipasi aktif dalam kegiatan desa, serta c) berkecimpung dalam kegiatan wisata desa. Bertindak selaku informan dalam penelitian ini sejumlah 4 orang yang terdiri dari 2 orang masyarakat desa, 1 orang perangkat desa Jatiguwi dan 1 orang pengelola lokasi wisata. Pengumpulan data dilakukan melalui wawancara mendalam kepada 4 orang informan tersebut. Teknik analisis data yang digunakan menggunakan analisis Miles dan Huberman dengan tahapan: reduksi data, penyajian data, penarikan kesimpulan dan verifikasi (Afrizal, 2017).

Tahapan analisis data meliputi reduksi data yakni dengan cara memilih dan memilah data primer dan skunder untuk persiapan analisis sesuai dengan indikator yang telah ditetapkan. Sebelum melakukan penyajian data maka memilih teori dan konsep yang tepat untuk mengupas hasil temuan di lapang. Langkah kedua adalah 
penyajian data berdasarkan hasil wawancara dari keempat informan. Penyajian data dilakukan dengan cara verbatim dan mereduksi hasil wawancara dengan sesuai dengan fokus penelitian. Pada tahapan ini terjadi diskusi anatar fakta lapang dengan teori dan konsep yang dijadikan acuan dalam penelitian ini. Langkah ketiga adalah penarikan kesimpulan, kesimpulan yang dimaksudkan adalah menyajikan data dengan menganalisis dengan teori serta konsep yang ada. Verifikasi dilakukan untuk menghasilkan kesimpulan dan memberikan rekomendasi untuk keberlanjutan kegiatan penelitian. Sedangkan fokus penelitian yang dianggap sebagai batasan penelitian ini meliputi a) komunikasi kelompok berbasis digital community development yang digunakan sebagai pelestarian kearifan lokal desa; b) kekuatan komunikasi kelompok yang ada di desa Jatiguwi berbasis digital; serta c) pelestarian kearifan lokal desa Jatiguwi berbasis digital.

\section{3 | HASIL DAN PEMBAHASAN}

Kearifan lokal yang ada di desa Jatiguwi meliputi sumber daya alam dan nilai yang tertanam di masyarakat secara turun temurun. Berdasarkan hasil wawancara yang dilakukan kepada informan didapatkan hasil bahwa masyarakat bekerjasama bahu membahu untuk kembali memberikan geliat terhadap Jurang Toleh Park (JTP) sebagai bentuk kearifan lokal yang berupa nilai. Nilai gotong royong dan kebersamaan yang masih kuat meminimalisir terjadinya konflik pada kelompok masyarakat. Sehingga banyak sekali kelompok yang dilibatkan dalam kegiatan penlestarian kearifan lokal dan kegiatan untuk meningkatkan pendapatan mayarakat desa. Tujuan utama yang ingin dicapai adalah meningkatnya pengunjung JTP. Untuk mencapai hasil maksimal, kegiatan yang dilakukan adalah melibatkan karamg taruna, kelompok pengelola wisata dan ibu rumah tangga dan kelompok ibu PKK. Bangunan fisik pada lokasi wisata JTP sudah terorganisir dengan baik, namun seperti yang telah dijelaskan pada latar belakang bahwa wisata edukasi ini masih belum berjalan secara optimal. Hal ini dikarenakan jumlah pengunjung JTP masih belum banyak. Sehingga tujuan utama dari pemberdayaan masyarakat adalah meningkatkan jumlah pengunjung, sehingga harapannya adalah mampu memberikan kontribusi ekonomi yang berdampak pada peningkatan perekonomian pada kelompok masyarakat di desa Jatiguwi terutama yang berada di sekitar lokasi wisata.

Kearifan lokal menjadi kekuatan pengembangan potensi di berbagai desa, seperti misalnya pada desa wisata Sade yang terletak di Lombok Tengah. Untuk meningkatkan kunjungan wisatwan dilakukan pengembangan tempat dan aktivitas wisata, akomodasi, akses ke tujuan tujuan wisata, sarana pendukung pariwisata, dan juga komunikasi pemasaran pariwisata (Hasanah, 2019). Merujuk pada 
peristiwa di atas, merancang strategi pemasaran merupakan aspek utama dalam meningkatkan jumlah pengunjung dan mengembangkan potensi wisata berbasis kearifan lokal. Sehingga lokasi wisata mampu bertahan dan bersaing serta menciptakan brand sampai cakupan internasional. Pemasaran pariwisata dilakukan dengan merancang bauran pemasaran, bauran iklan, bauran iklan, dan harga. Fokus penelitian ini adalah strategi memberdayakan kelompok untuk meningkatkan pariwisata berbasis kearifan lokal dengan menggunakan metode media digital. Langkah yang perlu dilakukan adalah meliputi peningkatan kapasitas sumber daya kelompok, pengenalan media digital, pembiasaan atas penggunaan media digital serta pengelolaan media digital seperti tergambarkan pada gambar 1.

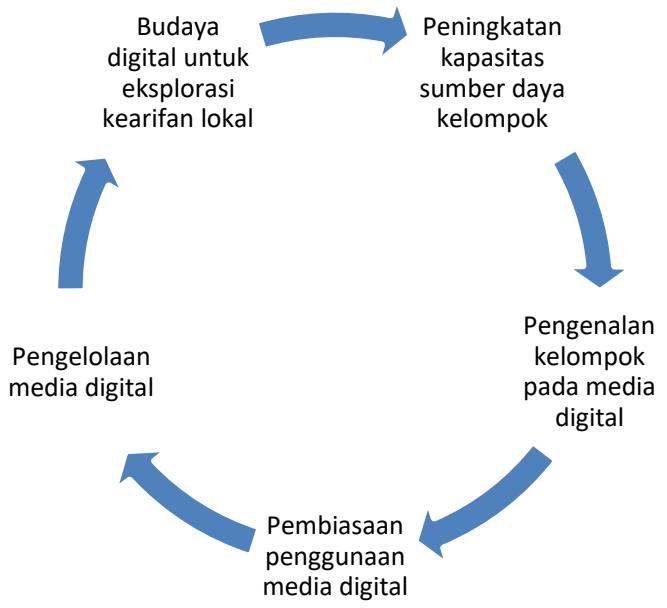

\section{Gambar 1. Langkah Digital Community Development Pada Kelompok Masyarakat Desa Jatiguwi}

(Sumber: Data Penelitian, 2020)

Kelompok ibu PKK dilibatkan dalam kegiatan pengelolahan souvenir dan ikonik JTP. Pelibatan kelompok ibu PKK disinergikan dengan kontribusi dari ibu rumah tangga dari keluarga yang berpenghasilan rendah di desa Jatiguwi. Peran yang diberikan kepada kelompok ibu PKK dan ibu rumah tangga adalah untuk membuat ikon kuliner dan jenis souvenir khas dari JTP. Souvenir dan ikon JTP telah ditetapkan antara lain dari segi kuliner (makanan khas), spot wisata dan potensi ikan air tawar. Upaya yang dilakukan kelompok PKK dan ibu rumah tangga dalam mebuat makanan khas JTP dapat menjadi ikon kuliner digiring melalui FGD dan melakukan eksplorasi terkait sumber daya alamiah yang terdapat di desa Jatiguwi. Selain itu berdasarkan pengalaman yang telah berjalan, selama ini pengunjung sama sekali tidak disuguhi kuliner khas JTP. Hal ini dikarenakan tidak ada stand khusus kuliner yang menyajikan masakan ikan air tawar. Dari hasil FGD bersama 
kelompok PKK dan ibu rumah tangga, potensi sumber daya alam berupa ikan air tawar dijadikan sebagai olahan utama ikon kuliner dari JTP. Sehingga ke depannya diharapkan bias menjadi andalan kuliner dari JTP dan desa Jatiguwi. Sedangkan untuk sumber daya alam yang dianggap sebagai kearifan lokal meliputi: bendungan yang terletak di desa Jatiguwi, ikan air tawar serta kuliner masyarakat setemapat.

Eksplorasi kearifan lokal yang dilakukan pada FGD kelompok PKK dan ibu rumah tangga juga dijalani oleh kelompok karang taruna dan pengelola wisata. Hal ini dilakukan dalam rangka menyinergikan kekuatan kelompok-kelompok masyarakat untuk mengelola kearifan lokal. Identifikasi kearifan lokal dilakukan sendiri oleh kelompok masyarakat, bertujuan untuk mengoptimalkan potensi kearifan lokal yang berdampak pada meningkatnya perekonomian masyarakat setempat. Setelah memiliki sinergitas bersama, kegiatan dapat dilakukan dengan meletakkan budaya teknologi pada setiap langkah yang diambil olek kelompok masyarakat dalam mengembangkan promosi wisata di JTP.

Kelompok ibu rumah tangga dan ibu PKK dilibatkan dalam melek media secara digital. Kelompok tersebut dilatih untuk menggunakan media sosial dan search engine (mesin pencari) seperti misalnya google. Hal ini diupayakan untuk meningkatkan kemampuan kelompok untuk mencari referensi dan mengelola potensi kuliner dari JTP. Seluruh menu kuliner dikelola secara langsung oleh kelompok ibu (rumah tangga dan PKK). Pengelolaan menu antara lain meliputi pemilihan menu, pemilihan bahan menu, pengelolaan penjualan, pendistribusian pesanan serta promosi kuliner secara digital. Semua proses tersbut dikelola oleh kelompok ibu rumah tangga dan kelompok ibu PKK. Seperti yang dikemukakan dalam penelitian Jakimow (2017) kekuatan kelompok atau kelompok perempuan dalam PKK sudah terbukti mampu menggerakkan perekonomian desa dan keluarga.

Pemandangan yang terdapat di JTP meliputi hamparan ratusan karamba budidaya ikan air tawar. Permasalahan yang muncul adalah belum memanfaatkan hasil budidaya ikan air tawar secara optimal. Dari hasil FGD bersama kelompok, awal yang tidak menyajikan kuliner air tawar, menyepakati untuk pengelolaan budidaya secara sentral yang berakhir untuk wisata kuliner di JTP. Padahal saat ini kuliner seringkali menjadi magnet lokasi wisata untuk dikunjungi banyak pengunjung. Dari hasil diskusi yang dilakukan akhirnya ditentukan kuliner khas JTP meliputi Kothokan Mujair, Nasi Tiga Warna, Teh Kelor, dan aneka olahan ikan air tawar. Menurut pemangku desa kekuatan desa Jatiguwi sehingga mampu membangun JTP adalah keterlimpahan ikan mujair dari bendungan dan kebun kelor. Sedangkan menurut masyarakat yang turut mengelola kearifan lokal setempat, produk daun kelor dapat diajdikan sebagai teh celup, sementara nasi tiga warna juga menjadi nasi yang seringkali dikonsumsi oleh masyarakat tersebut. Nasi 
tiga warna meliputi nasi beras (putih), nasi jagung (kuning) dan nasi tiwul (hitam/coklat) yang ketiganya mudah di dapatkan di Desa Jatiguwi. Rencana ke depannya ketiga warna tersebut dijadikan sebagai warna ikonik dari JTP. Namun, sejauh ini masih belum membahasnya secara serius. Sehingga menjadi rencana jangka panjang kelompok masyarakat untuk mengembangkan potensi kearifan lokal di desa Jatiguwi.

Kegiatan community development ini adalah upaya yang dilakukan oleh seluruh komponen masyarakat dari pemerintah desa yang dalam hal ini adalah Kepala Dusun/Kasun, masyarakat sekitar dan Karang Taruna selaku pengelola lokasi wisata yang ditunjuk oleh pemerintah desa. Masyarakat melakukan kegiatan bersih-bersih JTP setiap satu bulan sekali. Tim Karang Taruna sebagai pengelola juga selalu melakukan pemeliharaan lokasi dan upaya promosi melalui berbagai media. Tim Karang Taruna melakukan terobosan berupa penawaran Paket Wisata dimana di dalamnya termasuk paket kuliner yang bisa dipesan sebelum pengunjung mengunjungi area wisata. Pengunjung bisa memesan paket wisata melalui Karang Taruna, kemudian pihak karang taruna melakukan koordinasi dengan pihak PKK selaku penyedia makanan untuk memasak sesuai dengan pesanan. Saat pengunjung sudah datang maka Karang Taruna melakukan pelayanan. Selain paket kuliner pengunjung juga bisa memesan oleh-oleh yang juga ditawarkan oleh tim pengelola melalui media sosial. Oleh-oleh disediakan oleh kelompok PKK yang sudah dilatih untuk mampu membuat beberapa jenis olahan ikan air tawar dan teh kelor. PKK membagi tugas pada beberapa anggotanya dengan cara mengelompokkan anggota PKK berdasarkan perminatannya masing-masing. Ibuibu yang tertarik untuk mengolah Kothokan Mujair berkumpul dalam kelompok kothokan, yang tertarik bidang lain dikelompokkan berdasarkan jenisnya.

Pengelompokan ini juga sangat menguntungkan karena apabila salah satu anggota memiliki kesibukan dan tidak bisa menerima pesanan bisa dialihkan kepada anggota tim yang lain. Keuntungan yang di dapat dari kegiatan seperti ini adalah seluruh masyarakat memiliki rasa memilki (sense of belonging) terhadap JTP dan juga mendapatkan keuntungan dari banyaknya pengunjung yang datang. Seluruh komponen masyarakat bergoton royong untuk melakukan perbaikan terhadap pelayanan pengunjung JTP. Dari hasil wawancara yang dilakukan peneliti masyarakat juga akan melibatkan tokoh budayawan Desa agar terlibat dalam kegiatan di JTP.

Desa Jatiguwi juga memiliki salah satu desa cagar budaya untuk Topeng Malangan Madyo Laras yang sampai saat ini masih belum dikembangkan secara optimal. Dari kegiatan community development ini masing-masing orang akan termotivasi untuk menciptakan kreasi baik kreasi makanan, kerajinan ataupun makanan ringan yang berbeda-beda untuk memperkaya kekhasan JTP. Dari sini 
otomatis rasa saling menghormati karya orang lain, gotong royong dan bekerjasama menjadi aspek kearifan lokal yang berkembang dan berakar di masyarakat. Selain itu perhatian pemerintah desa selaku pemegang otoritas tertinggi juga menjadi salah satu penentu keberhasilan kegiatan ini. Kepala desa memberikan perhatian yang sangat serius terkait dengan kegiatan ini. Hal ini terbukti dengan dikucurkannya dana ADD untuk pembangunan JTP yang sangat besar. Pemerintah desa juga seringkali melakukan promosi baik melalui media sosial desa maupun dengan cara mengajak beberapa tamu desa untuk mengunjungi JTP.

Spot area pinggir waduk dijadikan sebagai lokasi wisata yang kemudian masyarakat lebih populer menyebutnya dengan Panorama Jurang Toleh atau Jurang Toleh Park (JTP). Lokasi ini dikembangkan masyarakat dengan tujuan untuk menambah pendapatan masyarakat di sekitar lokasi wisata dari pengunjung yang ingin menikmati pemandangan di Jurang Toleh. Pada awal pembukaan lokasi ini sekitar bulan Agustus 2017 banyak sekali pengunjung yang sekedar ingin menikmati suasana sore hari di tengah danau sambil berswafoto dengan latar matahari tenggelam. Pada awalnya pengunjung tidak dikenakan tiket masuk. Mereka hanya dibebani biaya parkir kendaraan motor saja. Lima ribu rupiah untuk sepeda motor dan sepuluh ribu rupiah untuk mobil. Akan tetapi seiring berjalannya waktu pengunjung semakin hari semakin sepi bahkan kadang tidak ada pengunjung sama sekali. Lokasi wisata yang dikembangkan dengan tujuan untuk meningkatkan tingkat ekonomi tinggal harapan belaka.

Jika melihat dari penjelasan para informan, masyarakat juga telah mengimplementasikan manajemen organisasi melalui peningkatan kapasitas kelompok, seperti yang pernah dikaji oleh Rinaldy (2017) melalui peningkatan pengetahuan dan pemahaman terkait dalam manajemen organisasi pada anggota kelompok atau kelompok. Penetrasi komunikasi digital yang telah dilakukan peneliti membawa dampak positif atas perubahan dalam mengelola kearifan lokal di desa Jatiguwi terutama dalam mengelola JTP. Hal ini dikarenakan JTP menjadi wadah untuk meningkatkan sumber perekonomian bagi masyarakat setempat. Sehingga peran serta masyarakat menjadi penentu keberhasilan obyek wisata ini. Digital community development yang telah dilakukan oleh peneliti telah melibatkan seluruh pihak untuk melakukan pemberdayaan berbasis digital. Obyek yang menjadi perhatian khususnya adalah kearifan lokal yang berimbas pada peningkatan perekonomian masyarakat desa melalui JTP. Penelitian ini masih menyisakan beberapa permasalahan karena batasan dari penelitian. Dari aspek komunikasi organisasi, masih membutuhkan dukungan manajerial dari pihak pemerintah desa. Pelibatan secara optimal pemerintah desa juga turut andil dalam keberhasilan pengembangan wisata untuk ke depannya. Sejalan dengan pemikiran Rizkianto \& Topowijono (2018), bahwa dukungan pemerintah desa mampu menggerakkan dan 
mengoptimalkan community development kelompok masyarakat dalam mengembangkan potensi wisata. Seperti studi kasus yang ada di desa wisata Bangun Kabupaten Trenggalek, seluruh pemangku desa terlibat aktif mulai perencanaan hingga evaluasi sehingga proses pengembangan berjalan seperti tujuan awal.

Proses optimalisasi kegiatan tersebut ditempuh melalui digital community development kepada perangkat desa serta masyarakat yang berada di sekitar lokasi wisata. Bentuk dari kegiatan di atas berupa pemberdayaan masyarakat desa Jatiguwi dengan meberikan literasi digital dalam memanfaatkan media digital. Dalam List (2019), pemberdayaan digital sangat efektif untuk mengembangkan potensi daerah melalui perspektif digital native, berbasis keterampilan, dan sosiokultural. Dari kondisi lapang dapat dijelaskan bahwa pendampingan yang telah dilakukan untuk kembali mewujudkan keinginan masyarakat terhadap keberadaan lokasi Wisata JTP. Kegiatan pendampingan yang dilakukan meliputi pembenahan lokasi wisata, penambahan spot-spot swafoto, pembersihan area, pelatihan komunikasi dan pelatihan lain berbasis kearifan lokal yang digunakan untuk memotivasi masyarakat agar kembali bersemangat untuk mengelola Panorama Jurang Toleh. Keberhasilan pemberdayaan dipengaruhi oleh intesifnya interaksi kelompok. Selain itu tingkat kepedulian dan partisipasi yang tinggi oleh masyarakat sekitar juga menjadi penentu keberhasilan digital community development.

Asas pelaksanaan kegiatan ini adalah pengembangan literasi digital yang dikembangkan secara mandiri, didorong oleh teknologi, atau berbasis proyek. Indikator keberhasilan kegiatan ini adalah mayarakat yang melek media digital dan juga mampu setidaknya menciptakan kebiasaan digital dalam kesehariannya. Meskipun jauh dari harapan untuk menciptakan budaya digital di skup desa, setidaknya masyarakat desa terutama kelompok masyarakat yang ada di desa mampu berkontribusi, berkompetisi dan berpikir kritis melalui pemanfaatan media digital. Selain itu, keberhasilan ini merupakan jawaban atas tantangan global untuk masyarakat desa di tengah himpitan perkembangan teknologi dengan laju yang sangat cepat. Percepatan atau akselerasi bagi kelompok masyarakat desa ini mampu memberikan nilai tersendiri bagi perubahan desa yang dimulai dari kelompok kecil. Tujuan jangka panjangnya adalah kelompok masyarakt yang terpilih seperti telah disebutkan di atas, memiliki tugas untuk menjadi peer education (kader) yang memberikan pendidikan teknologi digital bagi seluruh masyarakat yang ada di desa Jatiguri.

Oleh karenanya proses kegiatan ini sangat bergantung pada partisipasi langsung oleh masyarakat desa Jatiguwi. Literasi digital yang dibangun memiliki dua tujuan yakni pertama, melestarikan kearifan lokal dan kedua, meningkatkan perekonomian masyarakat desa. Obyek yang disasar oleh keduanya adalah wisata 
JTP, dimana dilakukan eksplorasi dari obyek wisata tersebut berbasis kearifan lokal yang ada. Sedangkan literasi digital yang dibangun digunakan untuk meningkatkan a) potensi wisata, b) pengunjung, c) pengelolaan wisata, serta d) promosi wisata.

Literasi digital yang digunakan untuk meningkatkan potensi wisata dilakukan melalui penciptaan sistem pembelian tiket online, pengelolaan keuangan secara online serta monitoring online. Selain itu, masyarakat juga diajarkan menggunakan media sosial untuk melakukan eksplorasi di dunia maya mengenai referensi kebrhasilan obyek wisata di daerah lain. Dalam hal meningkatkan pengunjung, digital literasi diposisikan sebagai nilai yang wajib dimiliki pengelola wisata untuk mengembangkan obyek wisata baik secara kuantitatif maupun kualitatif. Dan dalam hal promosi wisata, digital literasi digunakan untuk membuat media promosi secara digital. Pemanfaatan media sosial untuk melakukan eksplorasi dan mengaungkan JTP hingga ke mancanegara. Pengelolaan media sosial yang dilakukan secara mandiri oleh masyarakat menjadi output dalam penelitian ini.

Cara kerja digital community development sehingga dapat dianggap sebagai media yang mampu melestarikan kearifan lokal sekaligus meningkatkan perekonomian masyarakat desa terdapat empat tahap. Tahap pertama, melatih masyarakat yang terbita terkait literasi digital; kedua, melatih pembuatan konten digital untuk media promosi wisata; ketiga, membuat media promosi dan pengelolaannya; keempat, mengelola tempat wisata agar tetap berkesinambungan hingga meningkatkan perekonomian masyarakat desa. Cara kerja ini didukung oleh kesiapan dan mental perubahan masyarakat desa Jatiguwi terutama pemerintah desa dan pengelola wisata. Sinergitas semua warga mempermudah realisasi kegiatan ini.

Keberhasilan kegiatan pemberdayaan kelompok berbasis digital ini pada akhirnya memberikan keuntungan secara ekonomi bagai masyarakat desa Jatiguwi, terlebih pada pengelola wisata JTP. Hal ini juga dikarenkan partisipasi aktif warga untuk membangun JTP dan visi pemerintah desa untuk mengangkat potensi wisata desa yang ada di lingkungannya. Dari kegiatan pemberdayaan digital berbasis kelompok juga mampu merubah pola pemikiran masyarakat mengenai kemandirian terutama dalam konteks ekonomi. Masyarakat desa sudah tidak lagi banyak yang meninggalkan desa karena dapat memanfaatkan peluang ini menjadi peluang kerja. Warga di sekitar JTP mampu mengeksplorasi kemampuan memasak dan berbisnisnya dengan menerima pesanan oleh-oleh dan wisata kuliner yang menjadi program sebelumnya. Selain itu, karang taruna juga memiliki peluang untuk memberdayakan pemuda sekitar dengan menjadi tim promosi JTP dan memanfaatkan jejaring media sosial. Sedangkan PKK memiliki peran besar juga untuk mengembangkan wisata kuliner dan oleh-oleh. Ibu-ibu di desa Jatiguwi mampu berdaya secara ekonomi karena mereka mampu menghasilkan uang sendiri 
melalui komunikasi kelompok yang mereka jalin.

Kekuatan kelompok dan kelompok ini menjadi kearifan lokal baru yang harus dilestarikan secara berkesinambungan. Kelompok atau kelompok yang dilibatkan dalam digital community development antara lain: karang taruna, kelompok pemuda, ibu rumah tangga, PKK, dan pengelola wisata. Beberapa hal yang dihasilkan dari pemberdayaan kelompok adalah kelompok pemuda dan karang taruna mampu menciptakan lapangan pekerjaan baru. Selain itu memiliki pengalaman dalam melakukan pengelolaan promosi melalui media sosial. Ibu rumah tangga juga turut merasakan pemberdayaan dalam hal kemandirian perekonomian, mampu menciptakan sumber penghasilan sendiri. Sedangkan PKK berhasil menjadi organisasi yang inovatif yang menghasilkan konsep wisata kuliner beserta cara kerjanya. Pengelola wisata berhasil mengkoordinir warga sekitar untuk membuat system pengelolaan secara digital dan memberikan pelayanan yang prima kepada pengunjung.

\section{4 | SIMPULAN}

Penelitian ini mengerucutkan pada dua hal yakni pemberdayaan kapasitas kelompok berbasis digital dan pelestarian kearifan lokal berbasis digital untuk meningkatkan perekonomian masyarakat setempat. Kegiatan digital community development berhasil memperkuat pola komunikasi kelompok yang ada di desa Jatiguwi. Selain itu, output yang dihasilkan adalah peningkatan perekonomian dari peletarian kearifan lokal yang ada melalui obyek wisata Jurang Toleh Park (JTP). Keberhasilan ini diinisaiasi oleh kelompok masyarakat secara bersama-sama dengan didukung oleh seluruh komponen masyarakat di Desa Jatiguwi. Seluruh pengembangan kegiatan dilakukan dengan memaksimalkan kearifan lokal. Kearifan lokal meliputi sumber daya alam dan nilai yang dimiliki di desa Jatiguwi. Sedangkan pelibatan kelompok atau kelompok antara lain organisasi PKK, Karang Taruna serta pengelola wisata. Bentuk digital community development adalah literasi digital untuk meningkatkan potensi wisata, pengunjungm pengelolaan wisata dan promosi wisata. Sedangkan untuk mencapai keberhasilan literasi digital, melalui pelatihan literasi digital, pembuatan dan pengelolaan media promosi, pembuatan konten media promosi dan sistem pengelolaan wisata secara digital. Langkah digital community development pada kelompok masyarakat desa Jatiguwi antara lain: peningkatan kapasitas sumber daya kelompok, pengenalan media digital, pembiasaan atas penggunaan media digital serta pengelolaan media digital. Pada akhirnya membentuk budaya digital yang dapat digunakan untuk melestarikan kearifan lokal. Penelitian ini memiliki peluang kajian baru yakni berkaiatan dengan optimalisasi komuntas perempuan ibu rumah tangga dari keluarga pra sejahtera 
yang menopang keberhasilan promosi wisata.

\section{UCAPAN TERIMAKASIH}

Penelitian ini didanai oleh Kemenristek Dikti Melalui kegiatan Program Kemitraan Kepada Masyarakat (PKM). Perangkat Desa dan masyarakat Jatiguwi Kabupaten Malang, terima kasih atas partisipasi dan kerjasamanya dalam penelitian ini.

\section{REFERENSI}

Afrizal, M. (2017). Metode Penelitian Kualitatif. Raja Grafindo Pratama.

Akbar, M. F., Putubasai, E., \& Asmaria, A. (2019). Peran Komunikasi Dalam

Pembangunan Masyarakat. Komunika, 2(2), 111-127.

Albantani, A. M., \& Madkur, A. (2018). Think globally, act locally: the strategy of incorporating local wisdom in foreign language teaching in indonesia.

International Journal of Applied Linguistics and English Literature, 7(2), 1-8.

Boedijono, B., Wicaksono, G., Puspita, Y., Bidhari, S. C., Kusumaningrum, N. D., \& Asmandani, V. (2019). Efektifitas Pengelolaan Dana Desa Untuk Pembangunan Dan Pemberdayaan Masyarakat Desa di Kabupaten Bondowoso. Jurnal Riset Manajemen Dan Bisnis (JRMB) Fakultas Ekonomi UNIAT, 4(1), 9-20. https://doi.org/https://doi.org/10.36226/jrmb.v4i1.237

Farady Marta, R., Hafiar, H., Budi Setiawan, Y., Andriani, F., Lestari, P.,

Pamungkas, S., Ratri Rahmiaji, L., Alif, M., Yuli Purnama, F., \& Agustina Setyaningsih, L. (2019). Author compliance in following open journal system of communication science in Indonesia. Journal of Physics: Conference Series,

1175(1), 0-10. https://doi.org/10.1088/1742-6596/1175/1/012222 Gobyah, I. K. (2009). Pengenalan Keraifan Lokal Indonesia. Rineka Cipta. Handiwibowo, G. A. (2018). Singkronisasi Aktifitas Corporate Social Resposibility (CSR) dan Community Development (CD) dalam Konteks Pembangunan Berkelanjutan di Indonesia. IPTEK Journal of Proceedings Series, 5, 111-117. Hasanah, R. (2019). Kearifan Lokal Sebagai Daya Tarik Wisata Budaya di Desa Sade Kabupaten Lombok Tengah. DESKOVI: Art and Design Journal, 2(1), 4552. https://doi.org/http://dx.doi.org/10.51804/deskovi.v2i1.409

Ife, J. (2009). Alternatif Pengembangan Masyarakat di Era Globalisasi: Community Development. Pustaka Pelajar.

Jakimow, T. (2017). Volunteers' practices of care in community development as a model for citizenship in Medan, Indonesia. Citizenship Studies, 22(2), 145-159. Keraf, S. (2002). Etika Lingkungan. Penerbit Buku Kompas.

List, A. (2019). Defining digital literacy development: An examination of pre-service 
teachers' beliefs. Computers \& Education, 138(2), 146-158.

https://doi.org/https://doi.org/10.1016/j.compedu.2019.03.009

Mungmachon, M. R. (2012). Knowledge and local wisdom: Community Treasure.

International Journal of Humanities and Social Science, 2(13), 174-181.

Qamar, N., Badaru, B., \& Aswari, A. (2017). Local Wisdom Culture of Bugis-

Makassar in Legal Perspective. International Multidisciplinary Conference and

Call for Paper, 12, 87.

Rinaldy, R. (2017). Proses Community Development Pada Program Kampungiklim

Di Desa Cupang Kecamatan Gempol Kabupaten Cirebon. Jurnal Penelitian \&

PKM, 4(1), 15-22.

Rizkianto, N., \& Topowijono, T. (2018). Penerapan konsep community based tourism dalam pengelolaan daya tarik wisata berkelanjutan (Studi pada Desa Wisata Bangun, Kecamatan Munjungan, Kabupaten Trenggalek). Jurnal Administrasi Bisnis, 58(1), 20-26.

Sekarningrum, A. A., Lestari, P., \& Suparno, B. A. (2020). Manajemen Konflik

Komunikasi dalam Pengembangan Pariwisata Berbasis Masyarakat. Jurnal IImu Komunikasi, 17(3), 262-279.

Selasih, N. N., \& Sudarsana, I. K. (2018). Education Based on Ethnopedagogy in

Maintaining and Conserving the Local Wisdom: A Literature Study. Jurnal Ilmiah Peuradeun, 6(2), 293-306.

Setiyaningsih, L. A. (2017). Pelatihan Handycraft Talenan Vintage Dan Cyber

Promotion Untuk Ibu Rumah Tangga Berpenghasilan Rendah Kelurahan Kasin

Kota Malang. Jurnal Pengabdian Masyarakat Universitas Merdeka Malang, 1(1), 44-46. https://doi.org/10.26905/abdimas.v1i1.1174

Setiyaningsih, L. A., \& Fahmi, M. H. (2020). Penguatan Community Development

Petani Nanas Desa Palaan melalui Digital Marketing. Abdimas: Jurnal

Pengabdian Masyarakat Universitas Merdeka Malang, 5(2), 145-151.

https://doi.org/10.26905/abdimas.v5i2.4361

Setyowati, Y. (2019). Komunikasi pemberdayaan sebagai perspektif baru

pengembangan pendidikan komunikasi pembangunan di Indonesia. , 17(2),.

Jurnal Komunikasi Pembangunan, 17(2), 188-199.

Sufiyanto, S., Yuniarti, S., \& Andrijono, D. (2020). Sosialisasi dan Edukasi Penilaian Mandiri terhadap Risiko Penularan COVID-19 melalui InaRISK Personal.

Abdimas: Jurnal Pengabdian Masyarakat Universitas Merdeka Malang, 5(3), 209-219.

Sugiyono. (2017). Metode Penelitian Kuantitatif Kualitatif dan R\&D. Alfabeta.

Suri, D. (2019). Pemanfaatan Media Komunikasi dan Informasi dalam Perwujudan

Pembangunan Nasional. Jurnal Komunikasi Pembangunan, 17(2), 177-187. Syairozi, M., Rosyad, S., \& Pambudy, A. P. (2019). Pemberdayaan Masyarakat 
Sebagai Pengguna Kosmetik Alami Beribu Khasiat Hasil Produk Tani Untuk Meminimalkan Pengeluaran Masyarakat Desa Wonorejo Kecamatan Glagah

KAB. LAMONGAN. Empowering: Jurnal Pengabdian Masyarakat, 3(2), 88-98.

https://core.ac.uk/download/pdf/235216032.pdf

Uge, S., Neolaka, A., \& Yasin, M. (2019). Development of Social Studies Learning

Model Based on Local Wisdom in Improving Students' Knowledge and Social

Attitude. International Journal of Instruction, 12(3), 375-388.

https://doi.org/https://doi.org/10.293333/iji.2019.12323a

Umanailo, M. C. B. (2019). Integration of Community Empowerment Models

[Pengintegrasian Model Pemberdayaan Masyarakat]. Proceeding of Community

Development, 2, 268-277.

Wardhono, H., Budiyono, B., \& Hartati, F. K. (2020). Desa wisma siaga bencana di desa bungurasih sidoarjo. Journal Community Development and Society, 2(1), 34-41.

Widayati, S., Setyawan, P. E., \& Sonalitha, E. (2019). Panorama Jurang Toleh, Jatiguwi, Sumberpucung, Kabupaten Malang, Jawa Timur. Abdimas: Jurnal Pengabdian Masyarakat Universitas Merdeka Malang, 4(2), 12-17.

Widodo, A., Maulyda, M. A., Fauzi, A., Sutisna, D., Nursaptini, N., \& Umar, U. (2019). Tolerance Education Among Religious Community Based on the Local Wisdom Values in Primary Schools. Education and Social Sciences, 1, 327330. https://doi.org/https://dx.doi.org/10.2991/assehr.k.200827.082

Yuliasari, P. (2020). The Duality of Community Development and Community Relations Functions of Corporate Social Responsibility (CSR) Program: A Case Study of Oil and Gas Company in Subang, West Java. MASYARAKAT: Jurnal Sosiologi, 5(2), 51-80. https://doi.org/https://doi/org/10.7454/mjs.v25i1.11688 